\title{
Value Chain Analysis of Tea and Constraints Faced by the Small Tea Growers in India with Special Reference to State Assam
}

\author{
Abhijit Das ${ }^{1 *}$ and R.R. Mishra ${ }^{2}$ \\ ${ }^{1}$ Division of Dairy Economics, Statistics and Management, National Dairy Research Institute, \\ Karnal - 132001, Haryana, India \\ ${ }^{2}$ Department of Agricultural Economics, Dr. Rajendra Prasad Central Agricultural \\ University, Pusa - 848125, Samastipur, Bihar, India \\ *Corresponding author
}

\section{A B S T R A C T}

\section{Keywords}

Value chain, Small tea grower,

Constraints, Actors

Article Info

Accepted:

12 November 2019

Available Online:

10 December 2019
The study was carried out to estimating the cost involved in value addition of green tea leaves in Sonitpur district of Assam. The primary data were collected from 100 small tea growers drawn from fifteen randomly selected villages of two randomly selected blocks of Sonitpur district of Assam by conducting interview of individual respondents who were classified into lower-small, medium-small and higher-small tea growers on the basis of their land holdings. The secondary data were collected from various published and unpublished sources. It was found that the highest value addition took place at Industry level, where the cost of value addition was Rs. 129.18 per kilogram, followed by wholesalers (Rs.35.92 per kilogram), retailers (Rs. 17.80 per kilogram) and green leaf collector (Rs. 3.20 per kilogram). The analysis also revealed that the net incomes of small tea growers and green leaf collectors were Rs. 2.63 and Rs. 1.86 per kilogram of green tea leaves respectively; and for processors, wholesalers and retailers these were Rs. 20.00 , Rs. 2.50 and Rs. 4.00 per kilogram of made tea, respectively. It was observed that non-availability of workers in the peak plucking season, lower price of green tea leaves, non-settlement of land records of the small tea growers in the government offices and high price fluctuation of green tea leaves were the common problems faced by the small tea growers in the study area during production and marketing of green tea leaves.

\section{Introduction}

All over the world Tea is grown in more than 32 countries covering an area of more than 2.5 million hectares. Leading tea producing countries are India, China, Sri Lanka, Kenya and Indonesia. These five countries taken together account for 75 per cent of world's total tea production and 80 per cent of the world's tea exports. China is the largest producer of tea with annual production of 986.36 million $\mathrm{kg}$ out of total world tea production of 3728 million $\mathrm{kg}$. 
It accounts for 29.34 per cent of the world's production closely followed by India (26.44 per cent). In 2017 India's share in world tea exports was 12.9 percent (203.86 million $\mathrm{kg}$ ) out of the total export of 1578.56 million $\mathrm{kg}$ (Tea Statistics, Tea Board India, 2018). The production of tea in major tea producing countries in the world is given in Table 1.

Assam is the largest producer of quality tea in India, contributing about 51.90 per cent of the country's total tea production. During the year 2017 , out of a total area of 480.20 thousand ha and production of 983 million $\mathrm{kg}$, Assam alone accounted for 282.10 thousand ha of area and 657.24 million $\mathrm{kg}$ of production, constituting 58.72 per cent and 56.11 per cent of area and production respectively (Tea Statistics, Tea Board India, 2018).

The value chain is a concept which can be simply described as the entire range of activities required to bring a product from the initial input-supply stage, through various phases of production, to its final market destination.

Value is any activity that increases the market form or function of the product or service; and in today's business climate, there is a need to maximise the value of every process in a business (Jacoby, 2005). According to Hill \& Jones (2001) the term "value chain" refers to the concept that a company's chain of activities for transforming inputs into outputs with purpose to deliver value to the customers.

In the recent past the popularity of green tea leaf production from small tea farms increased manifold. More and more youths were attracted towards production of green tea leaves.

However, like other ventures, green tea leaf production too is not free from constraints. Small tea growers have to face many problems right from production of green tea leaves to its marketing.

\section{Materials and Methods}

\section{Selection of state}

The state of Assam covers 55.55 per cent area under tea cultivation in India and produces 51.90 per cent of country's total production of tea. Hence, Assam was chosen purposively for the study.

\section{Selection of district}

Out of all 33 districts of Assam, Sonitpur district is one of the leading tea growing districts of Assam and the rate of growth in the number of small tea growers in the district is very rapid and noticeable. Hence, Sonitpur district was chosen purposively for the study.

\section{Selection of blocks}

Sonitpur district has 7 community development blocks namely Balipara, Borchalla, Bihuguri, Dhekiajuli, Gabharu, Naduar and Rangapara. Out of these 7 blocks, Balipara and Dhekiajuli were selected randomly for the study.

\section{Selection of villages, small tea growers and intermediaries}

The Dhekiajuli block has 796 number of revenue villages (census 2011) out of which 10 leading tea growing villages namely, 1.No. HugrajuliBagan, Ali SingaGaon, DhekiajuliBagan, KachariGaon, HabiGaon, Ghoramora, MazbatGaon, PirakataGaon, Salmari, and SingariAtiGaon were selected.

The Baliparablock has 10 revenue villages (census 2011) out of which 5 tea growing villages namely Balipara, Chiloni, Chariduar, Dekargaon and Ghoramari were selected 
ramdomly. Out of the selected villages from the two blocks, 50 small tea growers were selected from villages under Dhekiajuli block and 50 small tea growers were selected from the villages under Balipara block randomly.

For the study of value chain of tea in the study area various intermediaries involved in the process were identified. The identified intermediaries were green leaf collector, processors, wholesalers and retailers. From each group of these intermediaries, 20 green leaf collectors, 5 processors, 20 wholesalers, 20 retailers were randomly selected for detailed study.

Constraints perceived by the respondents were priotized by using Garrett's ranking technique by using the following formula:

Percent position $=100\left(\mathrm{R}_{\mathrm{ij}}-0.5\right) / \mathrm{N}_{\mathrm{j}}$

Where

$\mathrm{R}_{\mathrm{ij}}=$ Rank given for the $\mathrm{i}^{\text {th }}$ variable by $\mathrm{j}^{\text {th }}$ respondents

$\mathrm{N}_{\mathbf{j}}=$ Number of variable ranked by $\mathrm{j}^{\text {th }}$ respondents

With the help of Garrett's Table, the percent position estimated is converted into scores.

The percentage position of each rank was converted into score using Garrett's table. For each constraint, score of individual respondents were added together and were then divided by the total number of respondents for whom the scores were added. Thus, the ranking was done on the basis of the mean score after arranging it in descending order.

\section{Results and Discussion}

Tea value chain was associated with the role of various players who controlled and added value along the chain. The players were green leaf collector, processors, wholesalers and retailers. There was no role of producers in tea value chain, they only related with cultivation of green tea leaves and the value addition starts from green leaf collector. Consumers were termed as supporters in the value chain as they made decision whether to purchase or not. The details of different actors and their roles in supply chain have been presented in Table 2.

The details of the operation of the value chain with reference to the year 2018-19 has been presented in Table 3 and Figure 1 and 2.

The tea growers were only related with tea production, therefore there was no special value addition occurred at tea growers' stage. The cost of production of 1.00 kilogram of green tea leaf was around Rs.16.90, and they sold these green leaves at a price Rs.19.54 per kilogram to the green leaf collector. Therefore their net income was Rs. 2.63 per kilogram of green tea leaves. The green leaf collectors sold the produce at Rs. 24.60 per kilogram and earned a net income of Rs. 1.86 per kilogram of green tea leaves. In the same way, the processors generated a net income of Rs. 20.00 per kilogram of made tea. The wholesalers and retailers generated a net income of Rs. 2.50 and Rs. 4.00 per kilogram of made tea respectively.

It was revealed from the table and figure that the highest value addition took place at Industry level, where the cost of value addition was Rs. 129.18 per kilogram followed by wholesalers (Rs.35.92 per kilogram), retailers (Rs. 17.80 per kilogram) and green leaf collector (Rs. 3.20 per kilogram). The reason for highest value addition at industry level as the processors had to bear cost of electricity, firewood, repair of machines, generator and lorry maintenance, taxes, wages, packing, brokerage, loading and unloading, warehousing and agent's 
commission. For producing 1.00 kilogram of made tea, processors had to buy $4.00 \mathrm{~kg}$ of green tea leaves. In that way cost at processing unit became very high. The activities performed by the processors have been presented on Figure 3.

In the recent past the popularity of green tea leaf production from small tea farms increased manifold. More and more youths were attracted towards production of green tea leaves. It was mainly because of higher profitability in green tea leaf production in the study area. However, like other ventures, green tea leaf production too is not free from constraints. Small tea growers had to face many problems right from production of green tea leaves to its marketing. The respondents were asked to report the constraints faced during production of green tea leaves. Their responses were recorded and analysed. The constraints were classified as production constraints, financial constraints, legal constraints and marketing constraints.

Table.1 Production of tea in major tea growing countries of the world (2015 to 2017)

\begin{tabular}{|c|c|c|c|c|}
\hline \multirow{2}{*}{ Sl.no } & \multirow{2}{*}{ Country } & \multicolumn{3}{|c|}{ Production in million $\mathrm{kg}$} \\
\hline & & 2015 & 2016 & 2017 \\
\hline 1 & China & $\begin{array}{c}936 \\
(27.00)\end{array}$ & $\begin{array}{c}1029 \\
(29.00)\end{array}$ & $\begin{array}{c}1095 \\
(29.34)\end{array}$ \\
\hline 2 & India & $\begin{array}{c}947 \\
(27.27)\end{array}$ & $\begin{array}{c}954 \\
(26.90)\end{array}$ & $\begin{array}{c}983 \\
(26.44)\end{array}$ \\
\hline 3 & Kenya & $\begin{array}{c}319 \\
(9.14)\end{array}$ & $\begin{array}{c}311 \\
(8.72)\end{array}$ & $\begin{array}{c}370 \\
(3.90)\end{array}$ \\
\hline 4 & Sri Lanka & $\begin{array}{c}328 \\
(9.45)\end{array}$ & $\begin{array}{c}315 \\
(8.77)\end{array}$ & $\begin{array}{c}309 \\
(8.20)\end{array}$ \\
\hline 5 & Turkey & $\begin{array}{c}137 \\
(3.92)\end{array}$ & $\begin{array}{c}145 \\
(4.10)\end{array}$ & $\begin{array}{c}179 \\
(4.66)\end{array}$ \\
\hline 6 & Indonesia & $\begin{array}{c}158 \\
(4.60)\end{array}$ & $\begin{array}{c}142 \\
(3.90)\end{array}$ & $\begin{array}{c}151 \\
(4.01)\end{array}$ \\
\hline 7 & Vietnam & $\begin{array}{c}135 \\
(3.85)\end{array}$ & $\begin{array}{c}145 \\
(4.00)\end{array}$ & $\begin{array}{c}149 \\
(3.97)\end{array}$ \\
\hline 8 & Bangladesh & $\begin{array}{c}63 \\
(1.70)\end{array}$ & $\begin{array}{c}52 \\
(1.50)\end{array}$ & $\begin{array}{c}59 \\
(1.55)\end{array}$ \\
\hline 9 & Malawi & $\begin{array}{c}39 \\
(1.08)\end{array}$ & $\begin{array}{c}46 \\
(1.28)\end{array}$ & $\begin{array}{c}49 \\
(1.36)\end{array}$ \\
\hline 10 & Uganda & $\begin{array}{c}39 \\
(1.08)\end{array}$ & $\begin{array}{c}36 \\
(1.02)\end{array}$ & $\begin{array}{c}46 \\
(1.37)\end{array}$ \\
\hline 11 & Tanzania & $\begin{array}{c}31 \\
(0.89)\end{array}$ & $\begin{array}{c}30 \\
(0.80)\end{array}$ & $\begin{array}{c}36 \\
(0.95)\end{array}$ \\
\hline 12 & Other Countries & $\begin{array}{c}353 \\
(10.12)\end{array}$ & $\begin{array}{c}356 \\
(10.10)\end{array}$ & $\begin{array}{c}353 \\
(10.12)\end{array}$ \\
\hline & World & $\begin{array}{l}3468 \\
(100)\end{array}$ & $\begin{array}{l}3553 \\
(100)\end{array}$ & $\begin{array}{l}3729 \\
(100)\end{array}$ \\
\hline
\end{tabular}

Source: Tea Statistics, Tea Board India (2018)

Figures in the parentheses indicate percentages 
Table.2 Different actors and their role in value chain

\begin{tabular}{|c|c|c|}
\hline Sl. no & Actors & Roles \\
\hline 1 & $\begin{array}{l}\text { Small tea } \\
\text { grower }\end{array}$ & Cultivation \\
\hline 2 & $\begin{array}{c}\text { Green leaf } \\
\text { collector }\end{array}$ & $\begin{array}{l}\text { Collection and transportation of green leaves from small tea } \\
\text { growers and delivering to processing unit } \\
\text { Sorting and quality control }\end{array}$ \\
\hline 3 & Processor & $\begin{array}{l}\text { Payment for the collected leaves and processing into different } \\
\text { types of tea. } \\
\text { Processing quality control. } \\
\text { Packing and labelling of final product }\end{array}$ \\
\hline 4 & Wholesaler & $\begin{array}{l}\text { Purchases bulk made tea (processed tea) from different } \\
\text { processors } \\
\text { Blending of bulk tea into convenient packing and value addition }\end{array}$ \\
\hline 5 & Retailer & $\begin{array}{l}\text { Customer relationship, sorting and advertisements of the product. } \\
\text { Quality control and monitoring }\end{array}$ \\
\hline 6 & Consumer & Making decision to purchase tea \\
\hline
\end{tabular}

Table.3 Average value realization of various actors in the tea value chain

\begin{tabular}{|c|c|c|c|c|c|c|c|}
\hline $\begin{array}{l}\text { SI. } \\
\text { No }\end{array}$ & Players & $\begin{array}{c}\text { Value Addition } \\
\text { process }\end{array}$ & $\begin{array}{c}\text { Cost of } \\
\text { procurem } \\
\text { ent per kg } \\
\text { ( Rs })\end{array}$ & $\begin{array}{c}\text { Total cost } \\
\text { of Value } \\
\text { Addition } \\
\text { per kg } \\
\text { ( Rs })\end{array}$ & $\begin{array}{c}\text { Total } \\
\text { product } \\
\text { ion cost } \\
\text { per kg } \\
\text { ( Rs })\end{array}$ & $\begin{array}{c}\text { Selling } \\
\text { price } \\
\text { per kg } \\
\text { (Rs })\end{array}$ & $\begin{array}{c}\text { Net } \\
\text { incom } \\
\text { e per } \\
\text { kg } \\
\text { ( Rs })\end{array}$ \\
\hline $\mathbf{1}$ & $\begin{array}{c}\text { Small tea } \\
\text { growers' } \\
\text { cost of } \\
\text { production }\end{array}$ & - & - & - & 16.91 & 19.54 & 2.63 \\
\hline $\mathbf{2}$ & $\begin{array}{c}\text { Green leaf } \\
\text { collectors }\end{array}$ & $\begin{array}{c}\text { Collecting green } \\
\text { leaves } \\
\text { And delivering to } \\
\text { processors }\end{array}$ & 19.54 & 3.20 & 22.74 & 24.60 & 1.86 \\
\hline $\mathbf{3}$ & $\begin{array}{c}\text { Processors } \\
\text { Converting green } \\
\text { tea leaf to made } \\
\text { tea, packing, } \\
\text { labelling }\end{array}$ & 24.60 & 129.18 & 153.78 & 173.78 & 20.00 \\
\hline $\mathbf{4}$ & $\begin{array}{c}\text { Wholesaler } \\
\text { s }\end{array}$ & $\begin{array}{c}\text { Blending and } \\
\text { packaging }\end{array}$ & 173.78 & 35.92 & 209.70 & 212.20 & 2.50 \\
\hline $\mathbf{5}$ & Retailers & $\begin{array}{c}\text { Sorting and sale } \\
\text { promotion and } \\
\text { quality control }\end{array}$ & 212.20 & 17.80 & 230.00 & 234.00 & 4.00 \\
\hline
\end{tabular}


Table.4 Production constraints faced by sample small tea growers

\begin{tabular}{|c|c|c|}
\hline Production constraints & Garrett Mean Score & Rank \\
\hline $\begin{array}{c}\text { Non availability of workers in peak } \\
\text { plucking season }\end{array}$ & 63.98 & I \\
\hline Erratic rainfall & 62.30 & II \\
\hline No- availability of inputs on time & 45.72 & III \\
\hline Unsuitability of certain soil type & 41.55 & IV \\
\hline $\begin{array}{c}\text { Lack of technical knowledge about } \\
\text { chemical use }\end{array}$ & 40.84 & V \\
\hline
\end{tabular}

Table.5 Financial constraints faced by sample small tea growers

\begin{tabular}{|c|c|c|}
\hline Financial constraints & Garrett Mean Score & Rank \\
\hline Lower price for green tea leaves & 76.00 & I \\
\hline Irregular payment of wages to workers & 52.98 & II \\
\hline High cost of inputs & 49.46 & III \\
\hline $\begin{array}{c}\text { Inadequate finance to start a new } \\
\text { plantation }\end{array}$ & 34.36 & IV \\
\hline
\end{tabular}

Table.6 Legal constraints faced by sample small tea growers

\begin{tabular}{|c|c|c|}
\hline Legal constraints & Garrett Mean Score & Rank \\
\hline $\begin{array}{c}\text { Non-settlement of land records of the } \\
\text { growers in the govt. offices }\end{array}$ & 54.20 & I \\
\hline $\begin{array}{c}\text { Non-existence of formal organization of } \\
\text { small tea growers }\end{array}$ & 40.72 & II \\
\hline
\end{tabular}

Table.7 Marketing constraints faced by sample small tea growers

\begin{tabular}{|c|c|c|}
\hline Marketing constraints & Garrett Mean Score & Rank \\
\hline High price fluctuation of green tea leaves & 76.00 & I \\
\hline Lack of adequate storage facilities & 48.80 & II \\
\hline Lack of adequate processing facilities & 48.68 & III \\
\hline Lack of transportation facilities & 39.91 & IV \\
\hline $\begin{array}{c}\text { Defective and faulty weighing of green tea } \\
\text { leaves }\end{array}$ & 38.91 & V \\
\hline
\end{tabular}


Fig.1 Total cost of value addition per kilogram of green tea leaf or made tea

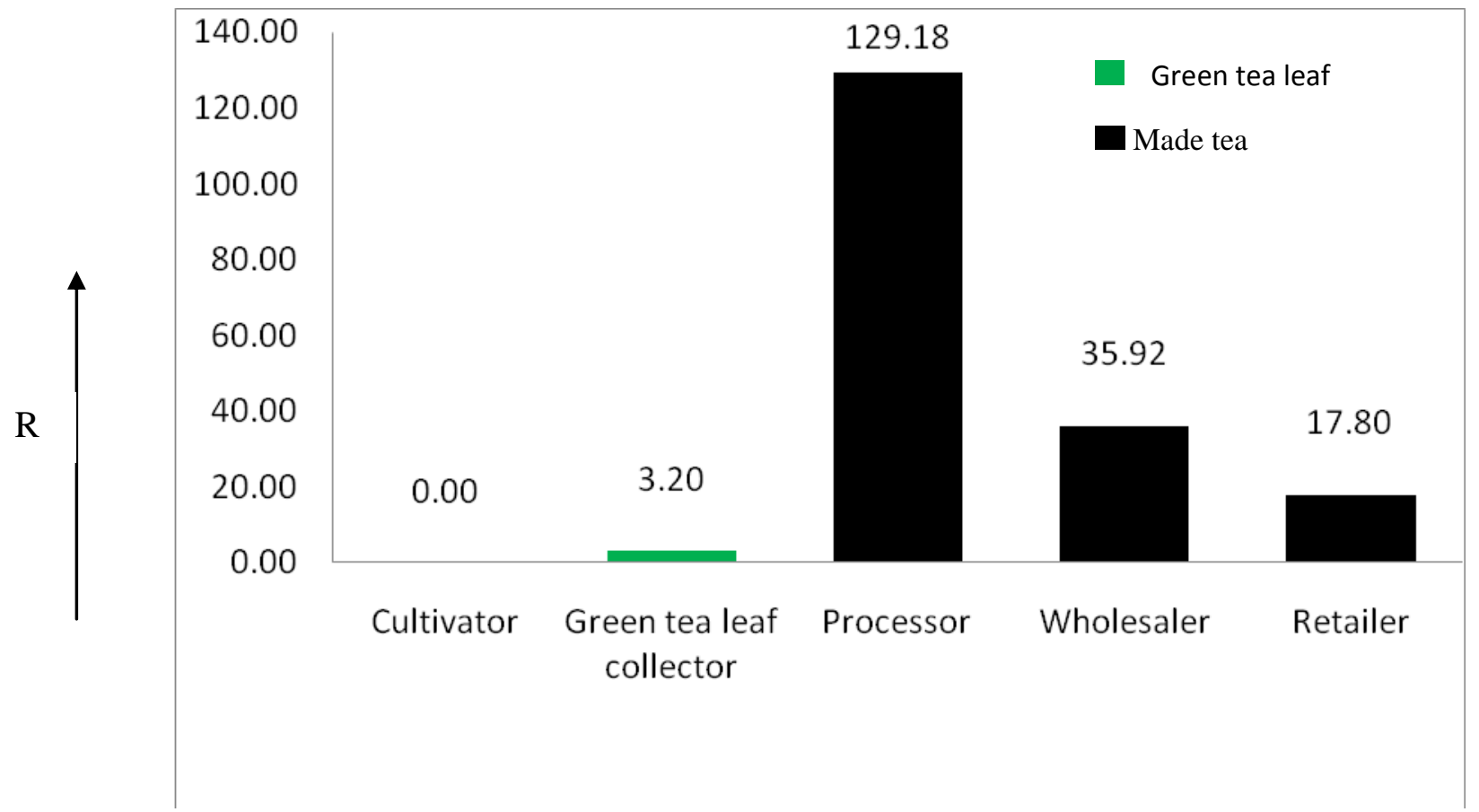

Fig.2 Net income of players per kilogram of green tea leaf or made tea

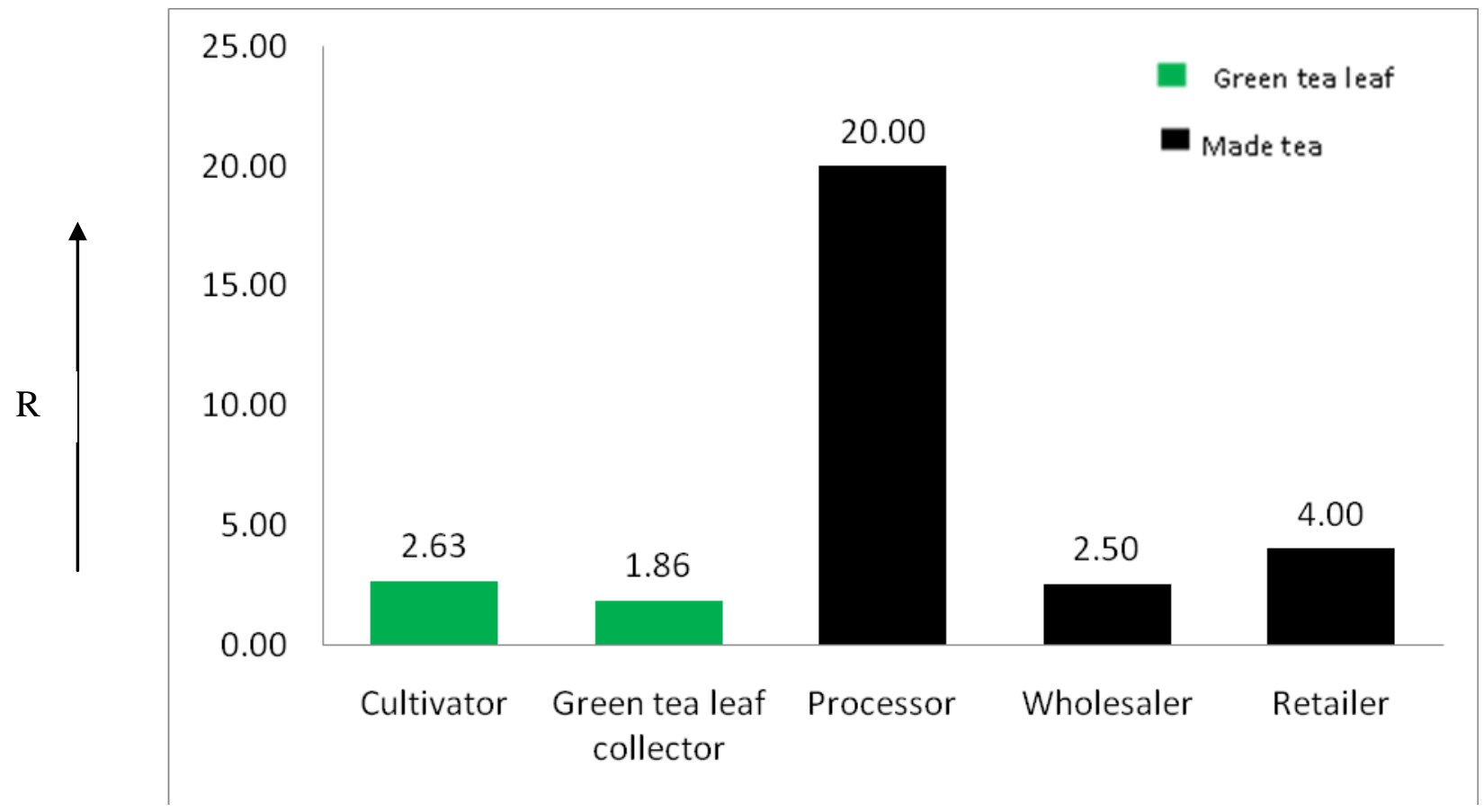


Fig.3 Activities performed by the processors

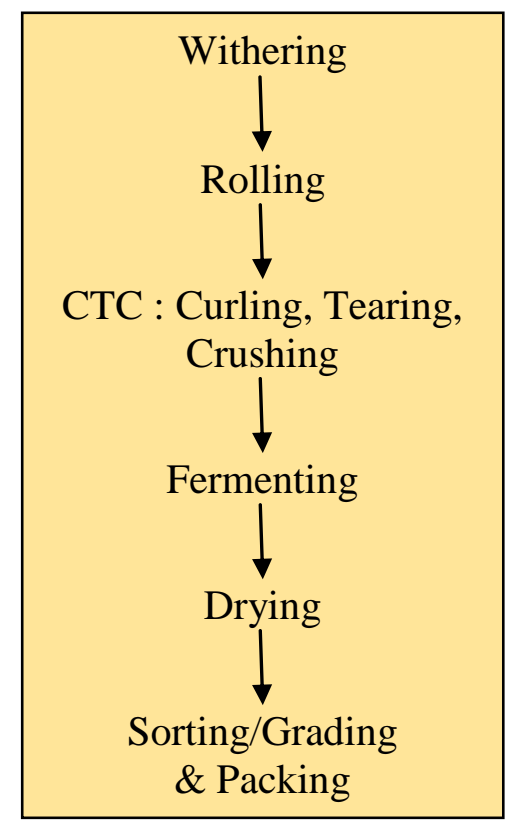

\section{Production constraints}

The problems faced the sample small tea growers throughout the green tea leaf production process were non availability of workers in peak plucking season, erratic rainfall, non-availability of inputs on time, unsuitability of certain soil type and lack of technical knowledge about chemical use. The data related to production constraints were analysed and the findings have been presented in Table 4.

The table revealed that, non availability of workers in the peak plucking season was considered as major problem faced by small tea growers with 63.98 average score in garret ranking, followed by problem of erratic rainfall, problem of non availability of inputs at time, unsuitability of certain soil type and lack of technical knowledge about chemical use with average score of $62.30,45.72,41.55$ and 40.84 respectively.

Migration of workers to other industrially advanced states in the expectation of higher wages was the main reason for nonavailability of workers during peak plucking season, that's why it was at number one position in the opinion of green tea leaf growers. Offer of higher wages to the workers during peak plucking season by the tea estates may be another reason for this constraint.

Large number of small tea growers were dependent on natural precipitation for tea cultivation, and erratic rainfall might led to low production of green tea leaves in the study area. Non-availability of inputs such as agrochemicals may be due to the fact that number of licensed agro-chemical suppliers was less as compared to number of small tea growers and suppliers were unable to fulfil the demand for agro-chemicals of small tea growers.

\section{Financial constraints}

Financial constraints included monetary problems faced by the small tea growers throughout the production process. It included lower price of green tea leaves, inability to provide wages regularly to workers, high cost 
of inputs, inadequate finance to start a new plantation. The data related to financial constraints has been presented in Table 5 .

It is clear from the table that the lower price of green tea leaves was the most important problem faced by the small tea growers with 76.00 score in garret ranking, followed by irregular payment of wages to workers, high cost of inputs and inadequate finance to start a new plantation with average score of 52.98, 49.46 and 34.36 respectively.

\section{Legal constraints}

Legal constraints included non-settlement of land records of the small tea growers in the government offices and non existence of formal organization of small tea growers. The data related to legal constraints has been presented in Table 6.

The table revealed that non-settlement of land records of the small tea growers in the government offices was considered as the number one problem with 54.20 average score in garret ranking, followed by non-existence of formal organization of small tea growers with 40.72 average score in garret ranking.

\section{Marketing constraints}

Marketing constraints involved problems faced by the small tea growers during marketing of green tea leaves. It included high price fluctuations, lack of adequate storage facilities, lack of adequate processing facilities, lack of transportation facilities and defective and faulty weighing of green tea leaves. The data related to marketing constraints has been presented in Table 7 .

It is clear from the table that, high price fluctuation of green tea leaves was considered as the most important problem faced by the small tea growers. The small tea growers expressed the view that inadequate storage facilities was the second most important constraints in green tea leaf production in the study area.

There was no proper processing facility in the study area for green tea leaf produced by the small tea growers. They thought that it was the next important problem faced by them. Unsatisfactory transportation facility and defective weighment of green tea leaves were other constraints as reported by small tea growers.

\section{References}

Arya, N. (2013) "Indian tea scenario". International Journal of Scientific and Research Publications, 3(7):1-10

Directory of small tea growers of Assam, Department of Industries \& Commerce, Government of Assam, 1:1-552

District Administrative Portal, Sonitpur district, Assam, India, www.sonitpur.nic.in

Food and Agricultural Organization of United Nations. (2015) "Value chain analyses for Shan tea and Arabica coffee under climate change in the northern mountainous region of Viet Nam". Economics and Policy Innovations for Climate-Smart Agriculture, 4:1-8

Goowalla, H. (2015) "A study on the problem and prospect of small tea growers in Assam with special reference to Jorhat district". International Journal of Science and Applied Science (IJSEAS), 1(4): 252-257

Jacoby A R., (2005). Achieving High Performance through Capabilities: What's Required to Dominate in the Service Business, Retrieved December 8, 2015, from Web site: http://www.accenture.com/Global/Res earch_and_Insights/By_Subject/Suppl 
y_Chain_Mgmt/AchievingBusiness.ht $\mathrm{m}$

Kakati, S. (2011) "Problems of small tea growers in Assam with special reference to Lakhimpur district". Economic and Political Weekly, 32(39):106-113

Kiran, R., Subhasini, K., and Harish, K. (2014) "Marketing and distribution practices of tea in Idukki district,
Kerala: A perspective”. International Journal of Innovative Research in Science, Engineering and Technology, 3(9): 16315-16321

Luttel, G. (2017) "Value chain analysis of coffee production in central Nepal". M.sc.(Ag.) Thesis. Tribhuvan university, Institute of agriculture and animal science postgraduate college, Kirtipur, Kathmandu, Nepal. Pp. 1-119

\section{How to cite this article:}

Abhijit Das and Mishra, R.R. 2019. Value Chain Analysis of Tea and Constraints Faced by the Small Tea Growers in India with Special Reference to State Assam. Int.J.Curr.Microbiol.App.Sci. 8(12): 1592-1601. doi: https://doi.org/10.20546/ijcmas.2019.812.191 